\title{
Pollen Grains Induce a Rapid and Biphasic Eczematous Immune Response in Atopic Eczema Patients
}

\author{
Kilian Eyerich $^{\mathrm{a}}$ Johannes Huss-Marp ${ }^{\mathrm{a}}$ Ulf Darsow $^{\mathrm{a}, \mathrm{b}} \quad$ Andreas Wollenberg $^{\mathrm{c}}$ \\ Stefanie Foerster ${ }^{a}$ Johannes Ring ${ }^{a, b}$ Heidrun Behrendt ${ }^{a}$ \\ Claudia Traidl-Hoffmann ${ }^{\text {a }}$ \\ a Division of Environmental Dermatology and Allergy GSF, ZAUM - Center for Allergy and Environment, \\ Technical University and ${ }^{\mathrm{b}}$ Department of Dermatology and Allergy, Technical University and \\ 'Department of Dermatology and Allergy, Ludwig Maximilians University, Munich, Germany
}

\section{Key Words}

Pollen · Atopic eczema $\cdot$ Nickel $\cdot$ Contact dermatitis

\begin{abstract}
Introduction: Eczematous reactions to type I allergy-inducing antigens are documented in a subgroup of patients with atopic eczema. Yet, the underlying immunological mechanisms are not well understood. Material and Methods: To delineate the effect of native pollen grains on human skin of healthy and atopic individuals we performed patch tests (atopy patch test with native pollen grains, PPT). Nickel patch tests (NPT) served as an established model of contact dermatitis. Skin site biopsies were taken 6-96 h after allergen application and investigated immunohistochemically. $\boldsymbol{R e}$ sults: Histology of positive patch tests showed an influx of mononuclear cells (predominantly CD4+, CD25+, CD45RO+). This influx was detected earlier in the PPT reaction than in the immune response to nickel. A biphasic cytokine response could be detected in the PPT: IL-5 dominated in the early,
\end{abstract}

Kilian Eyerich and Johannes Huss-Marp contributed equally to this work.

\section{KARGER \\ Fax +41613061234 E-Mail karger@karger.ch} www.karger.com
(C) 2007 S. Karger AG, Basel

$1018-2438 / 08 / 1453-0213 \$ 24.50 / 0$

Accessible online at:

www.karger.com/iaa
IFN- $\gamma$ in the late phase. The NPT was continuously dominated by IFN- $\gamma$. Dendritic cell subpopulations imitated the earlier kinetics of the mononuclear infiltrate. Discussion: Thus, pollen grains induce eczematous reactions in susceptible individuals. This reaction appears clinically and immunohistochemically similar to the contact hypersensitivity reaction to nickel but follows a faster kinetic and a biphasic course: Th2 and IgE in the early ( $24 \mathrm{~h}$ ) and Th1 predominance in the late (96 h) phase.

Copyright $\odot 2007$ S. Karger AG, Basel

\section{Introduction}

Atopic eczema (AE) [1] is a chronic relapsing inflammatory skin disease which is often associated with asthma and/or hay fever and a positive family history of atopy. Its main features are eczematous skin lesions with a typical, age-related distribution and severe pruritus $[2,3]$. It is a disease caused by combined influences of genetic and environmental factors [4] leading to a Th2-dominated immune response against various allergens [5]. Skin irritants, systemic or local infections, environmental pollutants, stress and hormonal changes may play an aggra-

Correspondence to: PD Dr. Claudia Traidl-Hoffmann

Division of Environmental Dermatology and Allergy TUM/GSF

Biedersteinerstrasse 29, DE-80802 Munich (Germany)

Tel. +49894140 3472, Fax +498941403453

E-Mail Claudia.Traidl-Hoffmann@lrz.tum.de 
vating role in the pathophysiology of $\mathrm{AE}[6,7]$. Especially aeroallergens may induce eczema flares $[8,9]$.

Current concepts follow the idea that allergens are able to penetrate the barrier-disturbed epidermis [10] where they are taken up by Langerhans cells which migrate to the regional lymph nodes and present the novel antigen to naïve $\mathrm{T}$ cells [11]. The relationship between antigen exposure via pollen grains and disease activity was already demonstrated as early as 1949 [12]. Notably, most recently a population-based panel study demonstrated that outdoor grass pollen exposure significantly exacerbated symptoms in children with eczema, especially in those sensitized against grass pollen [13]. These studies suggest that allergens which are known to induce type I allergy with the typical Th2-dominated immune response and production of specific IgE antibodies are also involved in the elicitation of eczematous reactions. The atopy patch test (APT) has been used as a model for early AE lesions $[14,15]$ and is performed with protein extracts of the respective allergen carrier, e.g. house dust mite or pollen $[16,17]$. The standardized APT technique has been developed in a series of multicentre trials and is regarded to be a suitable and reproducible procedure for evaluating the clinical relevance of IgE sensitization for eczematous skin lesions [18-20]. Since pollen themselves release not only allergens, but are rather a package of myriads of substances including the recently described proinflammatory and immunomodulatory lipid mediators ( pollen-associated lipid mediators - PALMs) [21-24], we exposed our patients and controls to native pollen grains.

The present study aims at analyzing an eczematous reaction to classically type I, IgE-mediated allergy-inducing agents. Since an eczematous reaction is traditionally contributed to type IV hypersensitivity-inducing agents we took the nickel patch tests (NPT) as reference inflammatory skin reaction in order to classify pollen eczematous reaction in the traditional model of types of hypersensitivity reactions to environmental substances.

\section{Materials and Methods}

\section{Patients and Subjects}

For the analysis of the time course of an acute eczematous reaction two different main groups were enrolled into the study following the declaration of Helsinki protocols after written informed consent had been given. (1) Patients with AE $(n=6)$ diagnosed according to the criteria of Hanifin and Rajka [25] sensitized against grass and/or birch pollen (specific IgE class 3 or higher) and with a positive APT. Allergen-specific and total IgE levels in serum were determined by CAP-FEIA (Pharmacia, Uppsala, Sweden). (2) Patients with positive NPT $(n=5)$ but negative personal and family history of AE or atopy. In addition, RAST and prick tests for 15 common allergens including birch and grass pollen were negative and total $\mathrm{IgE}$ was $<20 \mathrm{IU} / \mathrm{ml}$. (3) Healthy volunteers $(\mathrm{n}=4)$ without history and without clinical signs of atopy or other allergic diseases. (4) Patients with AE $(n=4)$ and sensitizations to grass and birch pollen but a negative APT. Biopsies from longlasting eczematous skin lesions (1 month) of an AE patient served as reference for a chronic lesion. None of the patients had received systemic steroids, antihistamines or UV light to the test site for at least 14 days prior to testing. The ethical committee of the Technical University of Munich approved the study.

\section{Pollen Patch Test and NPT}

Pollen patch tests (PPT) were performed using the standardized procedure of APT [18] with $1 \mathrm{mg}$ intact pollen grains instead of pollen extracts. Commercially available grass (Phleum pratense L.) and/or birch (Betula alba L.) pollen (Allergon, Ängelholm, Sweden) were applied in large Finn chambers (11 $\mathrm{mm}$ in diameter) on the back of the patients using petrolatum as a carrier. Petrolatum alone served as a negative control. After $48 \mathrm{~h}$ the Finn chambers were removed and the tested areas were marked. The test was evaluated after 48 and $72 \mathrm{~h}$. Positive reactions were classified according to the European Task Force on Atopic Dermatitis (ETFAD) 2000 reading key [8]. Epicutaneous provocation with nickel was performed using petrolatum containing $5 \% \mathrm{NiSO}_{4}$ [nickel(II)-sulfate 5\%, Hermal, Reinbeck, Germany] applied on the patients' back for $48 \mathrm{~h}$. The reactions were classified using the criteria of the International Contact Dermatitis Research Group and ranged between 1 and 3, according to the state of inflammation.

\section{Tissue Processing and Staining}

Punch biopsy specimens ( $5 \mathrm{~mm}$ in diameter) were taken under local anesthesia ( $1 \%$ lidocaine) from the centre of the patch test areas at various time points $(6,24,48,72,96 \mathrm{~h}$ after nickel/pollen application). Each patch test field was biopsied only once. Biopsies were immediately frozen at $-70^{\circ} \mathrm{C}$ and stored until further handling.

From these biopsies, 4 - $\mu$ m-thick sagittal cryostat sections were performed on a freezing microtome (cryostat Leitz 1720, Wetzlar, Germany) and mounted on glass slides coated with polyL-Lysine (Sigma, Munich, Germany). The slides were air-dried for $2 \mathrm{~h}$ and then fixed for $10 \mathrm{~min}$ in dry acetone (Sigma). Two slides of all specimens were stained with haematoxylin-eosin. The immunohistochemical staining was performed in part in the 'Tech Mate Horizon' (Dako, Hamburg, Germany) (table 1) according to the APAAP method.

Some stainings were performed manually (table 1): the sections were fixed with $3 \%$ buffered paraformaldehyde (Sigma) for $20 \mathrm{~min}$, washed in Trizma base buffer (Sigma) containing 1\% bovine serum albumin (Sigma) for $10 \mathrm{~min}$ and then incubated with the primary antibody diluted in antibody diluent (Dako, Hamburg, Germany) for $1 \mathrm{~h}$. After washing for $10 \mathrm{~min}$, the secondary antibody was added for $25 \mathrm{~min}$. After this step and repeated washing, alkaline phosphatase was added for $25 \mathrm{~min}$. The reactivity of this enzyme was visualized using the super sensitive detection kit (Bio Genex, San Ramon, Calif., USA). The activity of the alkaline phosphatase was inhibited by levamisole (Dako, Hamburg, Germany). Finally, all sections were washed again, slightly counterstained with haemalaun, washed and mounted in gelatine (Merck, Haar, Germany). 
Table 1. Characterization of antibodies used for immunostaining

\begin{tabular}{|c|c|c|c|c|}
\hline Antibodies & Isotype & Clone & Dilution & Source \\
\hline $\mathrm{CD}_{1} \mathrm{a}^{1}$ & $\operatorname{IgG} 2 \mathrm{a}$ & NA1/34 & $1: 50$ & Dako, Hamburg, Germany \\
\hline $\mathrm{CD}^{1}$ & polyclonal & polyclonal & prediluted & Dako, Hamburg, Germany \\
\hline $\mathrm{CD} 4^{1}$ & IgG1 & EDU-2 & $1: 50$ & NovoCastra, Dossenheim, Germany \\
\hline $\mathrm{CD}^{1}$ & IgG1 & $\mathrm{C} 8 / 144 \mathrm{~B}$ & prediluted & Dako, Hamburg, Germany \\
\hline $\mathrm{CD} 25^{1}$ & IgG1 & ACT-1 & $1: 100$ & Dako, Hamburg, Germany \\
\hline $\mathrm{CD}^{2} 5 \mathrm{RO}^{1}$ & IgG2a & UCHL-1 & prediluted & Dako, Hamburg, Germany \\
\hline BDCA22 & IgG1 & $\mathrm{AC} 144$ & AC144 & Miltenyi Biotec, Bergisch Gladbach, Germany \\
\hline $\mathrm{CD} \mathrm{b}^{2}$ & IgG1 & IOT6b & $1: 100$ & Immunotech, Marseille, France \\
\hline $\mathrm{F} c \varepsilon \mathrm{RI}^{2}$ & $29 \mathrm{C} 6$ & IgG1 & $1: 500$ & $\begin{array}{l}\text { J. Hakimi and R. Chizzonite, } \\
\text { Hoffmann-La Roche, Nutley, N.J., USA }\end{array}$ \\
\hline $\mathrm{CD}^{1} 4^{1}$ & IgG1 & 10.1 & $1: 100$ & BD Pharmingen, Heidelberg, Germany \\
\hline $\mathrm{CD}^{1} 8^{1}$ & IgG2b & $\mathrm{Y} 1 / 82 \mathrm{~A}$ & $1: 200$ & BD Pharmingen, Heidelberg, Germany \\
\hline IFN- $\gamma^{2}$ & IgG1 & 45.15 & $1: 50$ & Alexis, Grünberg, Germany \\
\hline $\mathrm{IL}-5^{2}$ & IgG1 & 9906.1 & $1: 300$ & R\&D, Minneapolis, Minn., USA \\
\hline $\operatorname{IgE}^{2}$ & IgG1 & CIA-E-7.12 & $1: 300$ & Dako, Hamburg, Germany \\
\hline
\end{tabular}

${ }^{1}$ Antibody was stained with the automated immunostainer, TechMate Horizon.

${ }^{2}$ Antibody was stained manually.

Light Microscopy: Quantification and Statistical Analysis

Microscopic investigation was performed with the Axioplan2 (Zeiss, Jena, Germany) light microscope. Immunohistochemical results were evaluated using the software programme 'KS300' developed by Zeiss which calculates the relative positive area in percent and the absolute positive area in square micrometres by measuring colour intensity. Quantification of two slides per stain was performed at $500 \times$ magnification in a blinded manner by two independent analyzers. Data from both analyzers was pooled. Quantification of the colour intensity was performed for dermis and epidermis. Since BDCA2 positivity was too low for a reliable online quantification, all BDCA2+ cells in a defined area (dermis and epidermis separately) were counted at $500 \times$ magnification by two independent investigators. The area of interest was defined using the software KS300. With these data, the number of cells per square millimetres was calculated for each biopsy.

Student's unpaired t test was used to compare the reactions of APT versus NPT and control groups. A p value $<0.05$ was considered significant.

\section{Results}

\section{Clinical Aspects of Patch Test Reactivity}

Native pollen grains induced acute eczematous reactions in patients with AE and known positive APT to pollen protein extracts $24-48 \mathrm{~h}$ after allergen application (data not shown). The test site showed an oedematous erythema with papules and seropapules resembling those seen in positive NPT. However, patients reacting to nick- el showed a slower kinetics: eczematous reactions were seen after $48-72 \mathrm{~h}$, while after $24 \mathrm{~h}$ none or only a slight erythema was observed. Notably, no acute eczematous reactions to native pollen grains were observed in $\mathrm{AE}$ patients with known sensitization against $P$. pratense or $B$. alba but negative APT in the past. None of our healthy controls showed a cutaneous reaction to native pollen grains. The petrolatum controls in all groups did not show any clinical signs of inflammation.

\section{Histological Evaluation of Skin Biopsy Specimens}

Hematoxylin-eosin-stained sections of biopsies taken from positive PPT and positive NPT showed a strong influx of mononuclear cells into dermis and epidermis. Acantholysis and intercellular oedema (spongiosis) were also observed in the epidermis. The strongest dermal and epidermal reaction was observed after 48 and $72 \mathrm{~h}$ for the PPT while the NPT showed a maximum after 72 and $96 \mathrm{~h}$. After $96 \mathrm{~h}$, the level of cellular infiltrate in the PPT was declining almost to the basic value, while in the NPT a strong infiltrate could still be observed (fig. 1a).

\section{Immunhistochemical Characterization of the T Cell Infiltrate}

Immunohistochemical analysis of the $\mathrm{T}$ cell infiltrate revealed that the majority of immigrating cells were $\mathrm{CD} 3+\mathrm{CD} 4+\mathrm{T}$ cells both in NPT and PPT (fig. 1b, 2). 


\section{CD3}
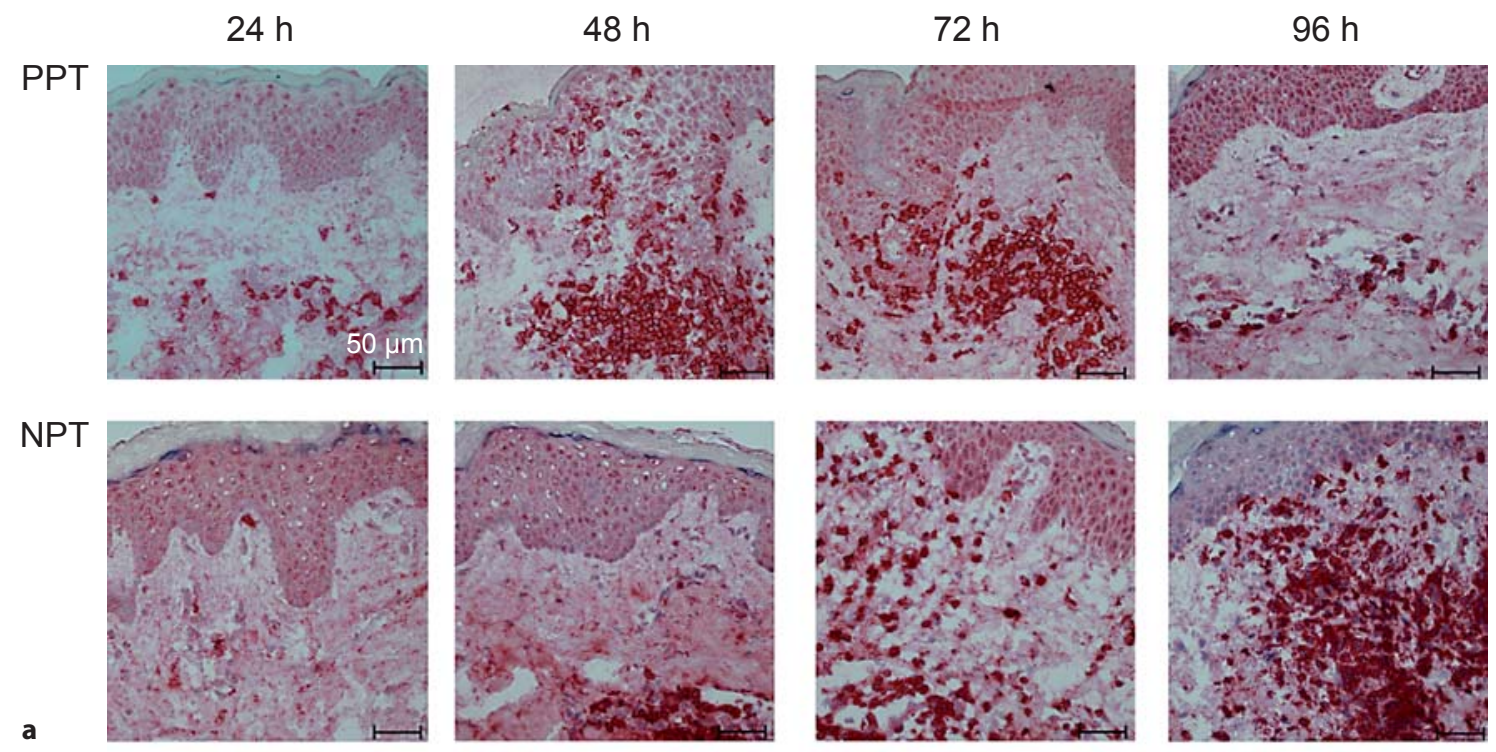

$\mathrm{PPT}+, 48 \mathrm{~h}$

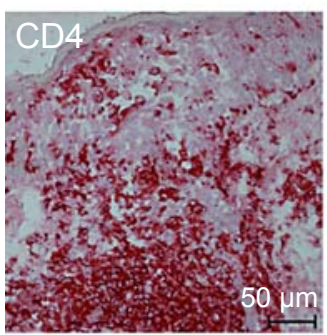

b

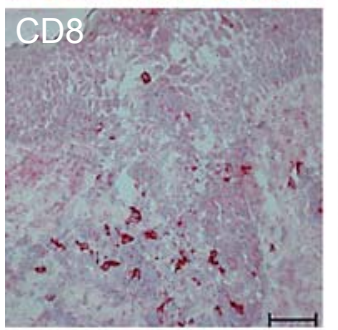

$\mathrm{NPT}+, 96 \mathrm{~h}$
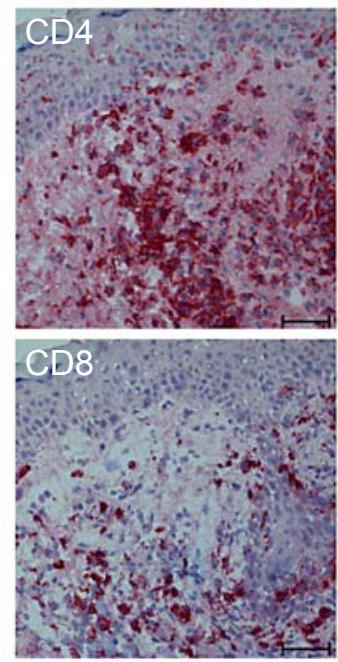
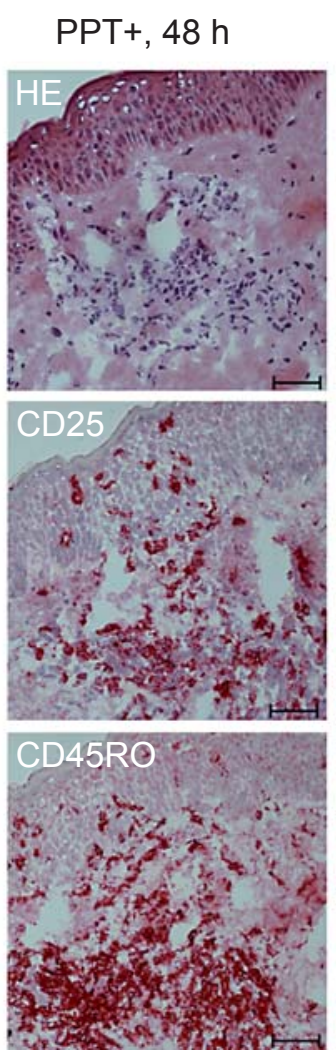

$\mathrm{NPT}+, 96 \mathrm{~h}$
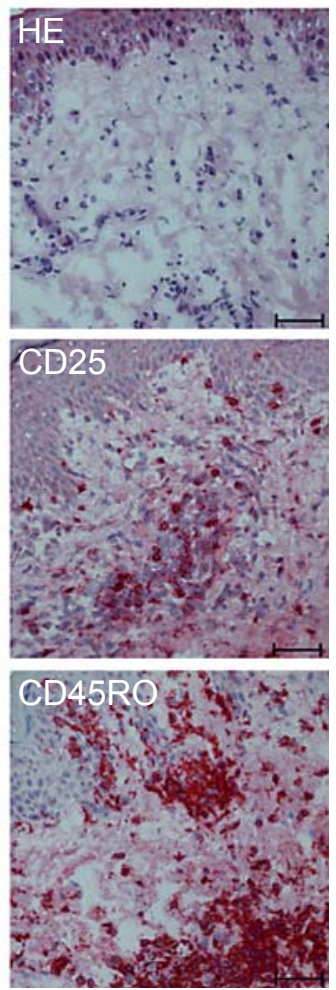

Fig. 1. Representative light micrographs of immunohistochemical stainings of PPT and NPT lesions. a The kinetics (24-96 h after allergen application) of the influx of CD3+ cells in PPT and NPT is shown for one patient each. $\mathbf{b}$ Characterization of the $\mathrm{T}$ cell infiltrate in PPT and NPT lesions (same patient as shown in a) at the climax of the immune reaction (PPT $48 \mathrm{~h}, \mathrm{NPT} 96 \mathrm{~h}$ after allergen application). c Immunohistochemical analysis of DC markers and
IgE in NPT and PPT lesions, magnification for BDCA2 staining $800 \times$, scale $=20 \mu \mathrm{m}$. d Representative staining for the cytokines IFN- $\gamma$ and IL-5 and monocyte/macrophage markers in PPT and NPT lesions at 48 and $96 \mathrm{~h}$ after allergen application. $\mathrm{HE}=\mathrm{Hae}-$ matoxylin-eosin; Epid. = epidermis. a-d Magnification 400× $($ scale $=50 \mu \mathrm{m})$ unless otherwise stated. 

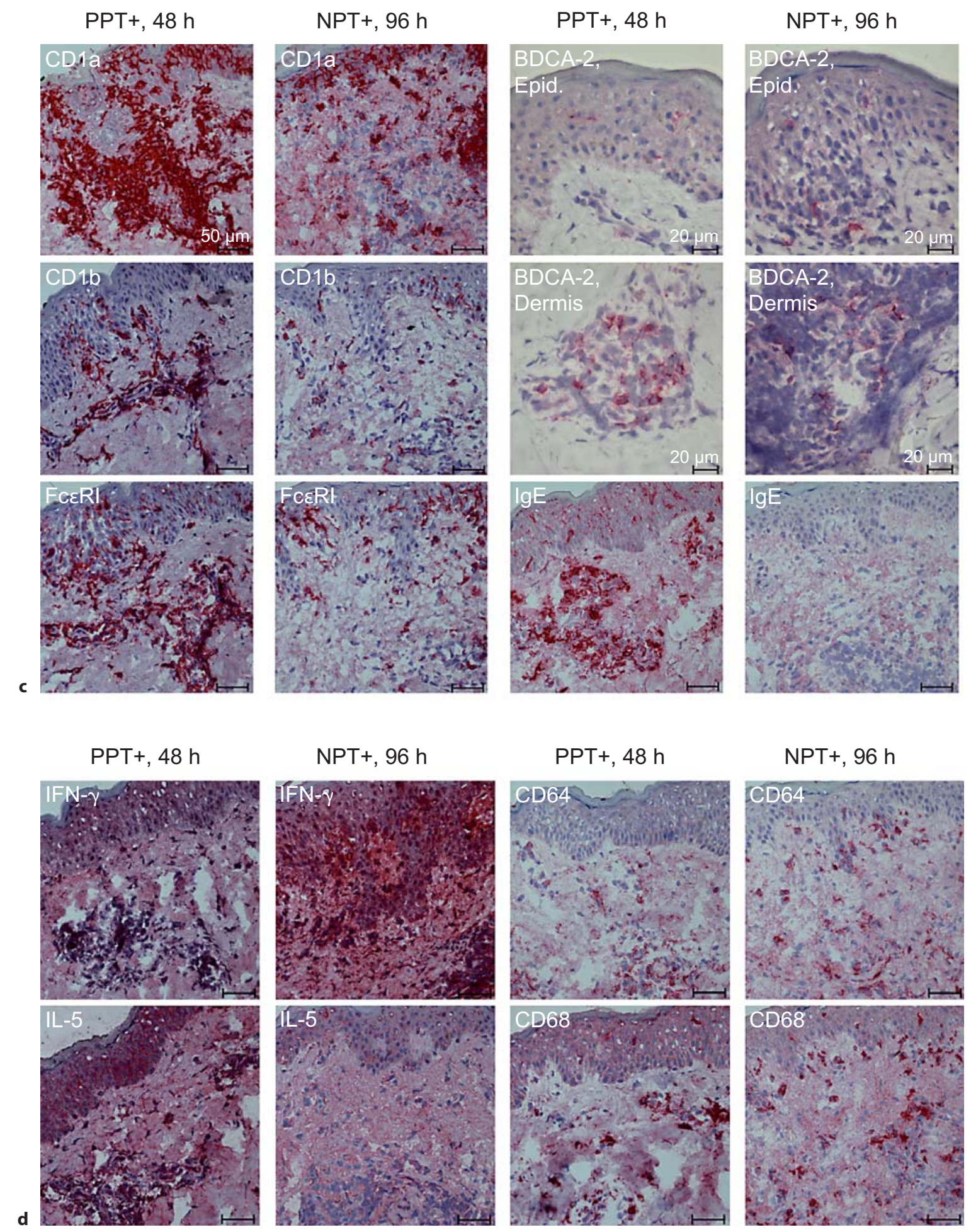
However, in APT the maximum influx of CD3+ T cells was lower compared to the NPT. An increase up to the late time point of $96 \mathrm{~h}$ of CD8+ cells was observed only in the NPT (fig. 2), while CD8+ cells in the PPT increased from 6 to $24 \mathrm{~h}$ and then remained on a level lower than that of the NPT until $96 \mathrm{~h}$ after allergen application. $\mathrm{CD} 4+\mathrm{T}$ cells increased continuously until $72 \mathrm{~h}$ in the PPT. In the case of NPT, a slight elevation until $48 \mathrm{~h}$ and a strong peak after $72 \mathrm{~h}$ were observed. Both reactions declined after $96 \mathrm{~h}$. Both NPT and PPT showed primarily an influx of CD45RO+ memory T cells. CD25+ cells showed a crescendo-decrescendo reaction both in NPT and PPT with a tendency - without significance $(\mathrm{p}=0.2$ for $48 \mathrm{~h}, \mathrm{p}=0.1$ for $72 \mathrm{~h}$ ) - of a higher percentage in the $\mathrm{PPT}$ reaction (fig. $1 \mathrm{~b}, 2$ ).

\section{Analysis of Antigen-Presenting Markers and IgE}

IgE positivity strongly increased in the positive PPT biopsies up to $24 \mathrm{~h}$ after pollen application and decreased continuously until $96 \mathrm{~h}$ but displayed still elevated levels compared to the other groups (fig. 1c, 3). IgE was found neither in the NPT+ biopsies nor in sections of healthy controls (fig. 3). FceRI-bearing cells were present after $24 \mathrm{~h}$ only in the PPT sections. They peaked at $24 \mathrm{~h}$ and remained elevated up to $96 \mathrm{~h}$. Both, the chronic AE lesion and the non-lesional skin of AE patients showed slightly elevated levels of FceRI-bearing cells. Normal, healthy skin from the non-atopic patients was almost negative for FceRI. The number of CD1a+ cells appeared higher in the PPT than in the NPT biopsies which was significant after $72 \mathrm{~h}(\mathrm{p}=0.037)$ (fig. 3). The chronic AE lesion showed a higher expression of CD1a in the epidermis (fig. 3). The most obvious difference between PPT and NPT occurred within the marker CD1b, staining primarily inflammatory dendritic epidermal cells (IDEC) [26], although overall positivity was low compared to CDla. CDlb+ cells increased in PPT rapidly between 6 and $24 \mathrm{~h}$, peaked at $24 \mathrm{~h}$ and remained at elevated levels (fig. 1b, 3). In contrast, in the NPT an increase in CD1b+ cells was only observed after $72 \mathrm{~h}$. In order to investigate the occurrence of plasmacytoid dendritic cells (pDC), we stained the sections for BDCA2. However, the rate of pDCs in all sections was too low for automatic quantification. So they were counted manually in the dermis and in the epidermis (fig. 1c, 3). Even though pDCs were present in the epidermis of both PPT and NPT lesions the occurrence of $\mathrm{pDC}$ was much lower compared to the dermis (ratio approximately 1:5, depending on the different time points). Comparable to the IDECs, dermal pDCs peaked at $48 \mathrm{~h}$ in PPT biopsies. In NPT sections the highest num- ber was observed after $72 \mathrm{~h}$. CD64, Fc $\gamma$ receptor I, expressed on macrophages and monocytes showed, as CD1b and BDCA2, a much faster kinetics in PPT compared to NPT (significant difference after $24 \mathrm{~h}, \mathrm{p}=0.039$ ) while the rate of CD68+ cells appeared equally over the time course in PPT and NPT, being slightly higher at $24 \mathrm{~h}$ $(\mathrm{p}=0.013)$ and $48 \mathrm{~h}(\mathrm{p}=0.528)$ in PPT sections but peaking at $72 \mathrm{~h}$ in both reactions (fig. 1d, 3). Notably, a faint positivity for the markers CD1b, CD64, CD68 and FceRI was observed in the negative APT, both from patients with $\mathrm{AE}$ and healthy controls.

\section{Cytokine Profile}

Sections were also stained for interleukin-5 (IL-5) and interferon- $\gamma($ IFN- $\gamma)$ in order to identify Th1- or Th2dominated immune responses. Both cytokine antibodies - IL-5 and IFN- $\gamma$ - showed typical cytoplasmic staining (fig. 1d). With regard to the T helper cell response, a clear dichotomy of the eczematous response to pollen in skin was observed while the NPT reaction was Th1 dominated over the entire time course of the eczematous reaction (fig. $4 \mathrm{a}, \mathrm{b}$ ). In the initiation phase of the eczematous reaction to pollen grains the IL-5 production was predominant over IFN- $\gamma$ production. In the late and chronic phases the situation was reversed and IFN- $\gamma$ production predominated over IL-5 production (fig. $4 \mathrm{~b}$ ). The biphasic course of the cytokine profile in PPT became most evident by the ratio of IFN- $\gamma$ and IL-5 positivity in the cryosections (fig. 4a).

\section{Discussion}

Eczematous reactions caused by type I allergy-inducing antigens seem to play a role in maintaining and exacerbating $\mathrm{AE}$, and yet the underlying mechanisms of this immune reaction are not well understood. In this study, we characterized the in vivo immune response to pollen grains immunohistochemically over a time course from 6 to $96 \mathrm{~h}$ after allergen application and compared it to the well-defined delayed-type hypersensitivity reaction to nickel. We found that both reactions were comparable in principle, but differed in three points: the PPT reaction to pollen followed a faster kinetics, the maximum intensity of the reaction was smaller and the infiltrating $T$ cells showed a biphasic cytokine profile.

Concerning the $\mathrm{T}$ cell infiltrate, the maximum intensity of the reaction reflected by the amount of $\mathrm{CD} 3+\mathrm{T}$ cells was higher in NPT than PPT sections, but the PPT reaction followed a faster kinetics. $\mathrm{CD} 8+\mathrm{T}$ cells became 

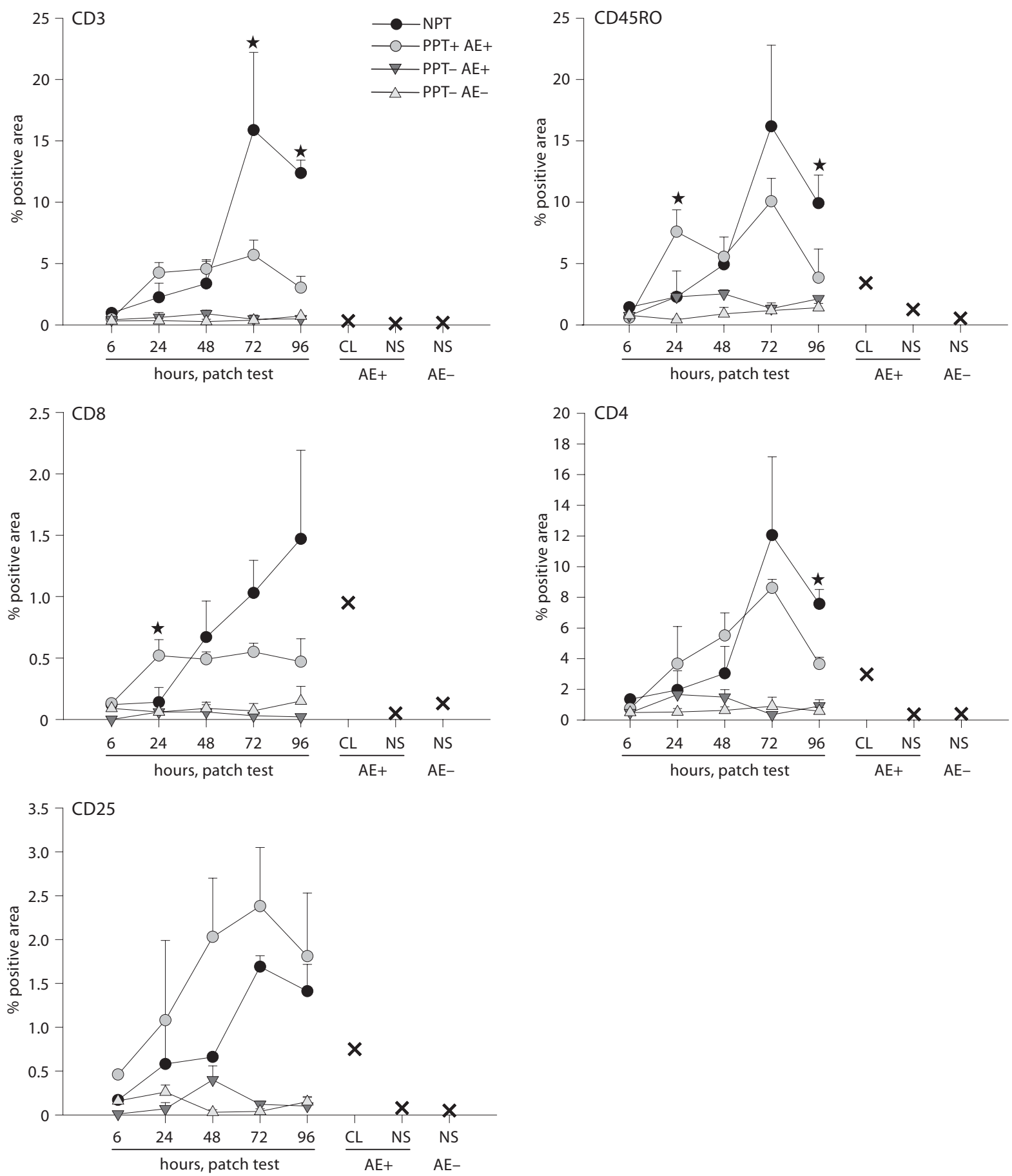

Fig. 2. Quantification of the T cell infiltrate in (PPT and NPT lesions: biopsies from PPT and NPT were taken 6-96 h after allergen application and stained for CD3, CD45RO, CD8, CD4 and CD25. Stained cryosections were quantified with the aid of the computer program KS300 (Zeiss, Jena, Germany). Mean \pm SEM of the percentage of the relative positive area of the respective antibody is shown from stained cryosections from 6 (positive PPT),
5 (positive NPT), and 4 (negative PPT in healthy donors and negative PPT in AE- patients) different donors. $\star=$ Significant ( $\mathrm{p} \geq$ 0.05 ) differences between positive APT and NPT biopsies. Furthermore, the results of the chronic AE lesion $(C L, n=2)$, the nonlesional skin of atopic patients (NS AE+, $n=2$ ) and normal skin of healthy volunteers (NS AE-, $n=2$ ) are shown on the right of the diagrams. 


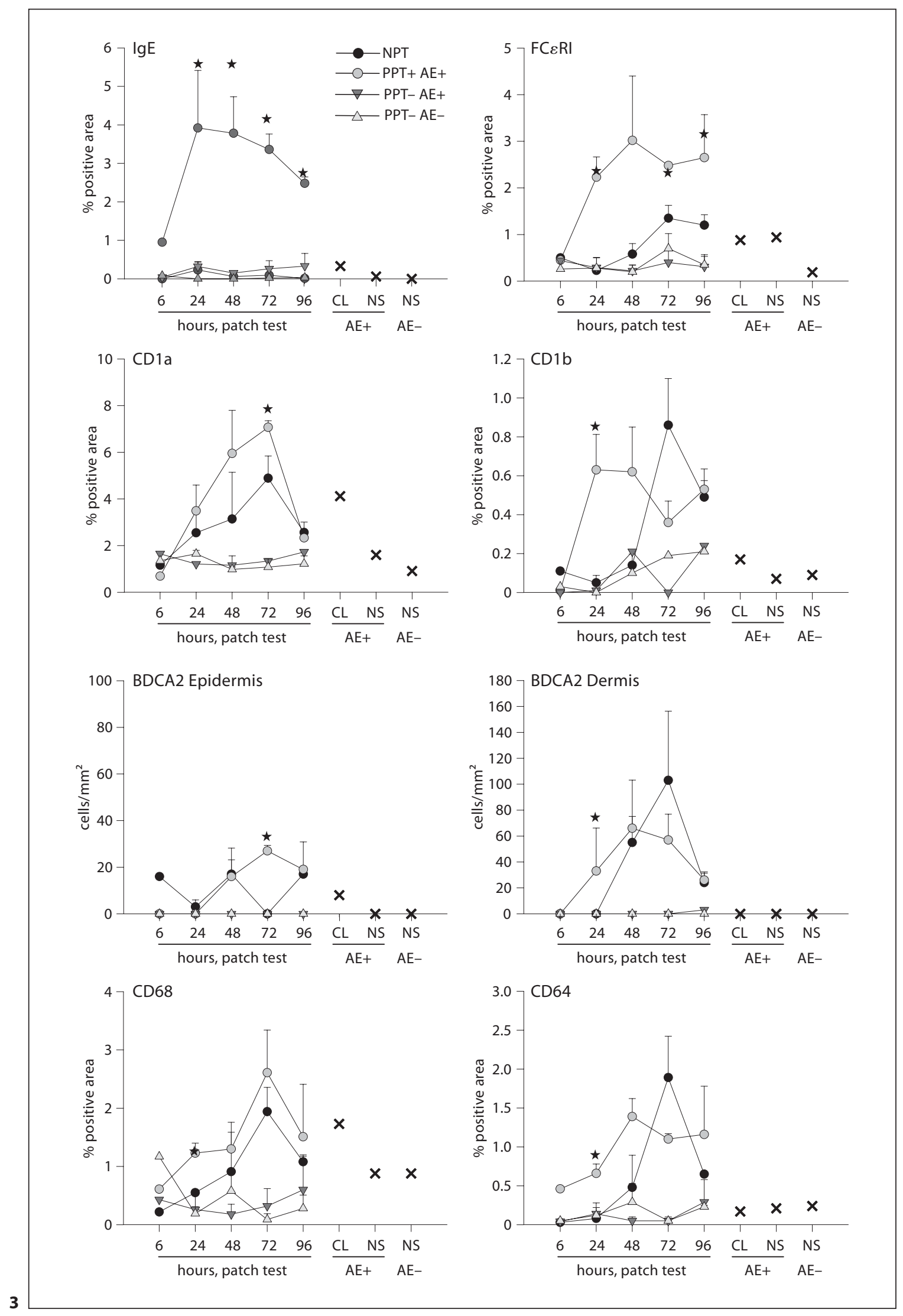


more prominent in the NPT lesions especially at late time points (72 and $96 \mathrm{~h}$ ) while they remained scarce in PPT sections. These results explain why a recent study investigating NPT described a much higher percentage of $\mathrm{CD} 8+$ when looking after $72 \mathrm{~h}$ [27]. At an earlier time point, our in situ results approximately correlate to the in vitro results from Werfel et al. [28] showing a proportion of $10-15 \%$ CD8+ allergen-specific T cells from lesional AE skin. Our results confirm previous reports $[29,30]$ demonstrating that more inflammatory cells are present in non-lesional AE skin compared to non-atopic skin, albeit in far smaller amounts than in lesional AE skin.

In both acute eczematous reactions (PPT and NPT) a predominance of memory $\mathrm{T}$ cells $(\mathrm{CD} 45 \mathrm{RO}+)$ was obvious. Furthermore, we detected a slightly enhanced expression of CD25 in the PPT compared to the NPT, but since CD25 is also expressed on DC, this could in part be due to the higher expression of DC markers in PPT and $\mathrm{AE}$ (chronic lesion and healthy skin of $\mathrm{AE}$ patient) and the earlier influx of DCs in PPT lesions.

Cytokines produced by subsets of $\mathrm{T}$ cells may play a role in regulating some of the features of atopic allergic inflammation. Staining for IFN- $\gamma$ and IL-5 revealed that at the early time points ( $24 \mathrm{~h}$ ) IL-5 dominated over the expression of IFN- $\gamma$ in the eczematous reaction to pollen grains while at the later time points $(96 \mathrm{~h})$ and in the chronic lesion IL-5 declined and an IFN- $\gamma$ dominance was observed. Thus, our observations of a biphasic course of the cytokine profile in acute eczematous reactions to native pollen grains extend previous studies performed

Fig. 3. Analysis of the expression of antigen-presenting cell markers and IgE in PPT and NPT lesions: cyrosections of all donors (see legend of fig. 2) were analyzed for the staining for IgE, FceRI, CD1a, CD1b (IDEC), BDCA2 (pDC in epidermis and dermis separately) and the macrophage and monocyte markers CD68 and CD64, respectively. Results are shown as mean values \pm SEM of positive staining area for the respective antibody quantified by KS300 computer software. $\star=$ Significant $(\mathrm{p} \geq 0.05)$ differences between positive PPT and NPT biopsies.

Fig. 4. Analysis of the cytokine profile in PPT and NPT lesions. a Ratio of the quantified relative positive area of IFN- $\gamma$ and IL-5 after 24-96 h after allergen application in NPT and PPT biopsy cryosections. $\mathbf{b}$ Mean \pm SEM of the quantified relative positive area for IFN- $\gamma$ and IL-5 in the time course of positive NPT $(\mathrm{n}=5)$, APT $(\mathrm{n}=6)$ and negative PPT $($ each $\mathrm{n}=4)$ in AE patients and healthy controls. Furthermore, results from chronic AE lesion $(\mathrm{CL}, \mathrm{n}=2)$, non-lesional skin of atopic patients (NS AE+, $\mathrm{n}=$ 2 ) and normal skin of healthy volunteers (NS AE-, n $=2$ ) are shown on the right . $\star=$ Significant $(\mathrm{p} \geq 0.05)$ differences between positive PPT and NPT biopsies.

Eczematous Reactions to Native Pollen Grains on APT reactions to house dust mite $[31,32]$. Taking our recent findings into account, the early Th2 response in the skin and the high IgE positivity in the PPT sections could in part be due to Th2-polarizing substances such
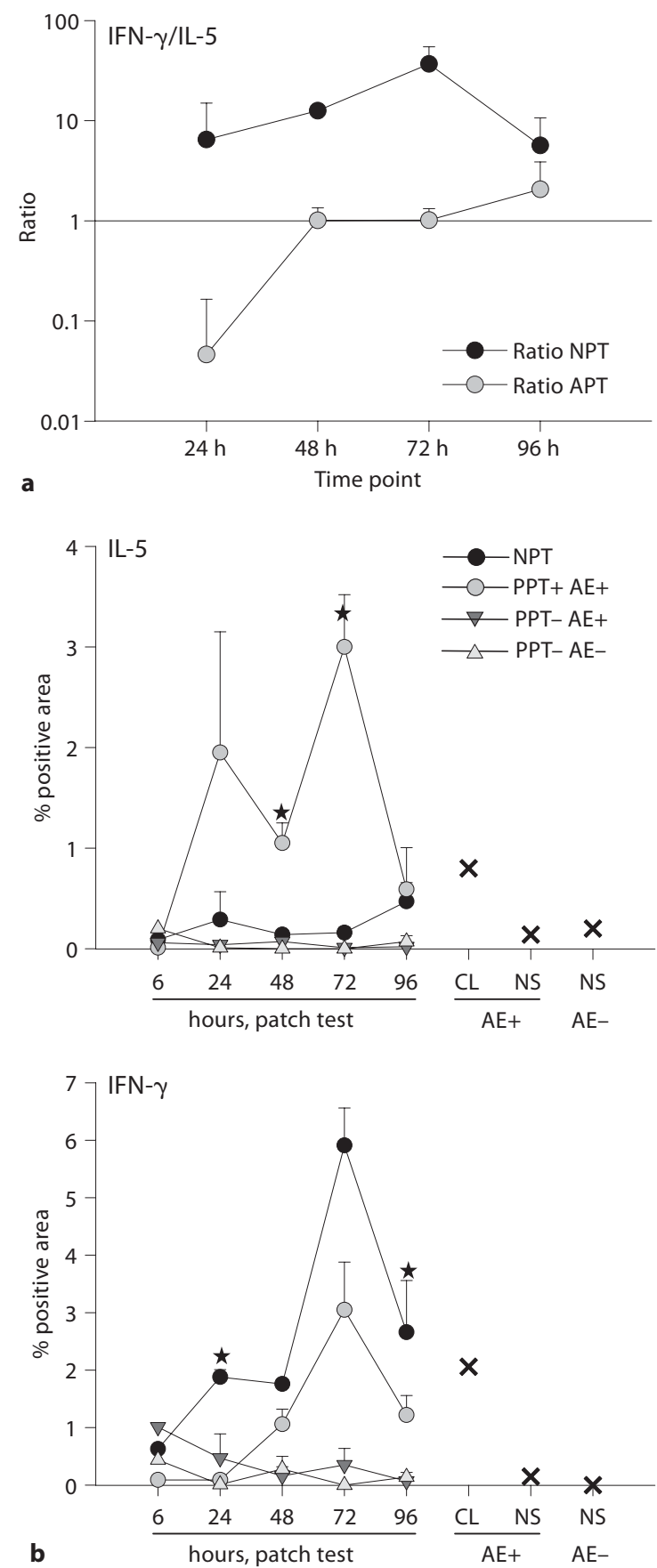
as phytoprostanes released from pollen itself [23]. The results of NPT showing a Th1 pattern over the whole time course are in line with data from the literature [33].

At the same time as the change in cytokine profile in PPT, we observed a substantial influx of macrophages and monocytes (CD64+, CD68+ cells) at PPT sites. Recently, macrophage-produced IL-12 was shown to be able to induce Th1 development in vitro [34]. This suggests that the influx of macrophages might induce a change in local skin microenvironment favouring IFN- $\gamma$. Interestingly, in the PPT lesion the decrease in early peaking IgE is accompanied by the increase in CD64, CD68 and the switch to the Th1 domination.

The elicitation of contact dermatitis presumably requires close interactions between infiltrating $\mathrm{T}$ cells and antigen-presenting cells, which either reside in the skin or migrate from blood. Langerhans cells are the resident DC population in skin epidermis where they form a contiguous network to detect any invading pathogen or antigen [35]. The significantly higher number of CD1a-expressing cells in the skin of $\mathrm{AE}$ patients as shown in the present study is of special interest with regard to the recent publication showing that lipids from pollen are presented in a CD1-restricted manner [36, 37]. A second CD1a+ epidermal DC population, the so-called IDEC [38], has been described to be the relevant IgE-binding, FceRI-expressing epidermal DC population in AE [39, 40]. In our study, CD1b, staining primarily IDECs, occurred in PPT as early as $24 \mathrm{~h}$ after pollen application while in the NPT an increase in CD1b positivity was observed earliest after $72 \mathrm{~h}$. This marker thus correlates with the faster clinical manifestation of acute eczema in PPT. Furthermore, it underlines the central role of IDECs in the development of the eczematous reactions in the early phase [26]. In the chronic AE lesion CD1b+ cells were scarce, but still more highly expressed than in nonlesional and healthy skin. In contrast to that, CD1a was also highly expressed in chronic lesions suggesting that the DC alteration during skin lesion formation can be subdivided into early and late events, with the influx of IDECs as an early event and the predominance of CDla+ cells as a late event.

pDC, also known as natural IFN- $\alpha / \beta$-producing cells [41], have been described to be present in skin in contact dermatitis and psoriasis and in a lower number in $\mathrm{AE}$ [42], where their inactivity is associated with eczema herpeticatum [43]. We observed an earlier influx of pDCs into the dermis in PPT $(24 \mathrm{~h})$ compared to the NPT $(48 \mathrm{~h})$. However, the percentage of pDCs in the epidermis was very low both in PPT and NPT lesions.
Negative results of PPT in patients with AE and sensitizations to pollen allergens were also observed by other authors [44]. It opens the question whether skin or even keratinocyte-specific factors play a role in these mechanisms. This idea is strengthened by the observation of positive PPT reactions in patients without sensitizations, intrinsic or non-AE, which were associated with an influx of IDEC [15]. Furthermore, this observation argues for allergen-specific rather than irritative factors accounting for eczematous reactions to native pollen grains. A question which cannot be answered in our setting of experiments, to some extent because of the low numbers of patients, is whether pollen grains are more competent to induce eczematous reactions compared to the prepared protein extracts for the APT.

In summary, we conclude that pollen grains induce an inflammatory reaction in susceptible individuals with AE. This reaction appears clinically and immunohistochemically similar to the known contact hypersensitivity reaction to nickel but follows a faster kinetics and a biphasic course - IL-5 and IgE in the early and IFN- $\gamma$ predominance in the late phase. The faster kinetics was also reflected by the rapid occurrence of DC, especially IDEC. Whether the early IL-5 dominance could be in part due to the recently described Th2-polarizing pollen-associated lipid mediators remains to be investigated.

\section{Acknowledgments}

We thank Alexandra Rizos and Sandra Goldonienko for outstanding technical assistance and Jarema Kochan for providing the 29C6 monoclonal antibody.
References
1 Johansson SG, Bieber T, Dahl R, Friedmann PS, Lanier BQ, Lockey RF, Motala C, Ortega Martell JA, Platts-Mills TA, Ring J, Thien F, Van Cauwenberge P, Williams HC: Report of the Nomenclature Review Committee of the World Allergy Organization, October 2003. J Allergy Clin Immunol 2004;113:832-836.

2 Ring J, Ruzicka T, Przybilla B (eds): Handbook of Atopic Eczema. Berlin, Springer, 1993, pp 3-8.

3 Hanifin JM: Basic and clinical aspects of atopic dermatitis. Ann Allergy 1984;52:386395.

4 Williams HC: Atopic Dermatitis: the Epidemiology, Causes and Prevention of Atopic Eczema. Cambridge, Cambridge University Press, 2000.

5 Leung DY, Bieber T: Atopic dermatitis. Lancet 2003;361:151. 
6 Mempel M, Lina G, Hojka M, Schnopp C, Seidl HP, Schafer T, Ring J, Vandenesch F, Abeck D: High prevalence of superantigens associated with the egc locus in Staphylococcus aureus isolates from patients with atopic eczema. Eur J Clin Microbiol Infect Dis 2003; 22:306-309.

7 Hashizume H, Horibe T, Ohshima A, Ito T, Yagi $\mathrm{H}$, Takigawa M: Anxiety accelerates Thelper 2-tilted immune responses in patients with atopic dermatitis. Br J Dermatol 2005; 152:1161-1164.

8 Darsow U, Ring J: Airborne and dietary allergens in atopic eczema: a comprehensive review of diagnostic tests. Clin Exp Dermatol 2000;25:544-551.

9 Morren MA, Przybilla B, Bamelis M, Heykants B, Reynaers A, Degreef H: Atopic dermatitis: triggering factors. J Am Acad Dermatol 1994;31:467-473.

10 Gondo A, Saeki N, Tokuda Y: Challenge reactions in atopic dermatitis after percutaneous entry of mite antigen. Br J Dermatol 1986;115:485-493.

11 Maurer D, Ebner C, Reininger B, Fiebiger E, Kraft D, Kinet JP, Stingl G: The high affinity IgE receptor mediates IgE-dependent allergen presentation. J Immunol 1995;154:62856290.

12 Tuft LA: Importance of inhalant allergen in atopic dermatitis. J Invest Dermatol 1949;12: 211-218.

13 Kramer U, Weidinger S, Darsow U, Mohrenschlager M, Ring J, Behrendt H: Seasonality in symptom severity influenced by temperature or grass pollen: results of a panel study in children with eczema. J Invest Dermatol 2005; 124:514-523.

14 Billmann-Eberwein C, Rippke F, Ruzicka T, Krutmann J: Modulation of atopy patch test reactions by topical treatment of human skin with a fatty acid-rich emollient. Skin Pharmacol Appl Skin Physiol 2002;15:100-104.

15 Kerschenlohr K, Günther S, Darsow U, Ollert M, Wollenberg A: Clinical and immunological reactivity to aeroallergens in 'intrinsic' atopic dermatitis patients. J Allergy Clin Immunol 2003;111:195-197.

16 Ring J, Darsow U, Gfesser M, Vieluf D: The 'atopy patch test' in evaluating the role of aeroallergens in atopic eczema. Int Arch Allergy Immunol 1997;113:379-383.

17 de Bruin-Weller MS, Knol EF, BruijnzeelKoomen CA: Atopy patch testing - a diagnostic tool? Allergy 1999;54:784-791.

18 Darsow U, Vieluf D, Ring J: Atopy patch test with different vehicles and allergen concentrations: an approach to standardization. J Allergy Clin Immunol 1995;95:677-684.

19 Darsow U, Vieluf D, Ring J: The atopy patch test: an increased rate of reactivity in patients who have an air-exposed pattern of atopic eczema. Br J Dermatol 1996; 135:182186.

20 Darsow U, Vieluf D, Ring J: Evaluating the relevance of aeroallergen sensitization in atopic eczema with the atopy patch test: a randomized, double-blind multicenter study. J Am Acad Dermatol 1999;40:187193.

Eczematous Reactions to Native Pollen Grains
21 Traidl-Hoffmann C, Kasche A, Jakob T, Huger M, Plötz S, Feussner I, Ring J, Behrendt $\mathrm{H}$ : Lipid mediators from pollen act as chemoattractants and activators of polymorphonuclear granulocytes. J Allergy Clin Immunol 2002;109:831-838.

22 Plötz S, Traidl-Hoffmann C, Feussner I, Kasche A, Feser A, Ring J, Jakob T, Bgehrendt $\mathrm{H}$ : Chemotaxis and activation of human peripheral blood eosinophils induced by pollen associated lipid mediators. J Allergy Clin Immunol 2004;113:1152-1160.

23 Traidl-Hoffmann C, Mariani V, Hochrein H, Karg K, Wagner H, Ring J, Mueller MJ, Jakob T, Behrendt H: Pollen-associated phytoprostanes inhibit dendritic cell interleukin-12 production and augment $\mathrm{T}$ helper type 2 cell polarization. J Exp Med 2005;201:627-636.

24 Mariani V, Gilles S, Jakob T, Thiel M, Mueller MJ, Ring J, Behrendt H, Traidl-Hoffmann $\mathrm{C}$ : Immunomodulatory mediators from pollen enhance the migratory capacity of dendritic cells and license them for Th2 attraction. J Immunol 2007;178:7623-7631.

25 Hanifin JM, Rajka G: Diagnostic features of atopic dermatitis. Acta Derm Venereol (Stockh) 1980(suppl 92):44-47.

26 Kerschenlohr K, Decard S, Przybilla B, Wollenberg A: Atopy patch test reactions show a rapid influx of inflammatory dendritic epidermal cells in patients with extrinsic atopic dermatitis and patients with intrinsic atopic dermatitis. J Allergy Clin Immunol 2003; 111:869-874.

27 Bangert C, Friedl J, Stary G, Stingl G, Kopp $\mathrm{T}$ : Immunopathologic features of allergic contact dermatitis in humans: participation of plasmacytoid dendritic cells in the pathogenesis of the disease? J Invest Dermatol 2003;121:1409-1418.

28 Werfel T, Morita A, Grewe M, Renz H, Wahn U, Krutmann J, Kapp A: Allergen specificity of skin-infiltrating T cells is not restricted to a type- 2 cytokine pattern in chronic skin lesions of atopic dermatitis. J Invest Dermatol 1996;107:871-876.

29 Bos JD, Hagenaars C, Das PK, Krieg SR, Voorn WJ, Kapsenberg ML: Predominance of 'memory' T cells (CD4+ CDw29+) over 'naive' T cells (CD4+ CD45R+) in both normal and diseased human skin. Arch Dermatol Res 1989;281:24-30.

30 Lever A, Turbitt M, Sanderson A, Mackie R Immunophenotyping of the cutaneous infiltrating and of the mononuclear cells in the peripheral blood of patients with atopic dermatitis. J Invest Dermatol 1987;89:4-7.

31 Thepen T, Langeveld-Wildschut EG, Bihari IC, van Wichen DF, van Reijsen FC, Mudde GC, Bruijnzeel-Koomen CA: Biphasic response against aeroallergen in atopic dermatitis showing a switch from an initial TH2 response to a TH1 response in situ: an immunocytochemical study. J Allergy Clin Immunol 1996;97:828-837.

32 Grewe M, Walther S, Gyufko K, Czech W, Schopf E, Krutmann J: Analysis of the cytokine pattern expressed in situ in inhalant allergen patch test reactions of atopic dermatitis patients. J Invest Dermatol 1995;105:407-410.
33 Tsicopoulos A, Hamid Q, Varney V, Ying S, Moqbel R, Durham SR, Kay AB: Preferential messenger RNA expression of Th1-type cells (IFN-gamma+, IL-2+) in classical delayedtype (tuberculin) hypersensitivity reactions in human skin. J Immunol 1992;148:20582061

34 Hsieh CS, Macatonia SE, Tripp CS, Wolf SF, O'Garra A, Murphy KM: Development of Th1 CD4+ T cells through IL-12 produced by Listeria-induced macrophages. Science 1993;260:547-549.

35 Bennett CL, van Rijn E, Jung S, Inaba K, Steinman RM, Kapsenberg ML, Clausen BE: Inducible ablation of mouse Langerhans cells diminishes but fails to abrogate contact hypersensitivity. J Cell Biol 2005;169:569-576.

36 Agea E, Russano A, Bistoni O, Mannucci R, Nicoletti I, Corazzi L, Postle AD, De Libero G, Porcelli SA, Spinozzi F: Human CD1-restricted T cell recognition of lipids from pollens. J Exp Med 2005;202:295-308.

37 Russano AM, Agea E, Corazzi L, Postle AD, De Libero G, Porcelli S, de Benedicits FM, Spinozzi F: Recognition of pollen-derived phosphatidyl-ethanolamine by human CD1d-restricted gamma delta T cells. J Allergy Clin Immunol 2006;117:1178-1184.

38 Wollenberg A, Kraft S, Hanau D, Bieber T: Immunomorphologic and ultrastructural characterization of Langerhans cells and a novel, inflammatory dendritic epidermal cell (IDEC) population in lesional skin of atopic eczema. J Invest Dermatol 1996;106: 446-453.

39 Wollenberg A, Haberstock J, Teichmann B, Wen S, Bieber T: Demonstration of the low affinity IgE receptor FceRII/CD23 in psoriatic epidermis: inflammatory dendritic epidermal cells (IDEC) but not Langerhans cells are the relevant CD1a-positive cell population. Arch Dermatol Res 1998;290:517-521.

40 Wollenberg A, Wen S, Bieber T: Phenotyping of epidermal dendritic cells: clinical applications of a flow cytometric micromethod. Cytometry 1999;37:147-155.

41 Colonna M, Trinchieri G, Liu YJ: Plasmacytoid dendritic cells in immunity. Nat Immunol 2004;5:1219-1226.

42 Wollenberg A, Wagner M, Günther S, Towarowski A, Tuma E, Moderer M, Rothenfusser S, Wetzel S, Endres S, Hartmann G: Plasmacytoid dendritic dells: a new cutaneous dendritic cell subset with distinct role in inflammatory skin diseases. J Invest Dermatol 2002;119:1096-1102.

43 Wollenberg A, Wetzel S, Burgdorf WH, Haas $\mathrm{J}$ : Viral infections in atopic dermatitis: pathogenic aspects and clinical management. J Allergy Clin Immunol 2003;112: 667-674.

44 Langeveld-Wildschut EG, Bruijnzeel PL, Mudde GC, Versluis C, Van Ieperen-Van Dijk AG, Bihari IC, Knol EF, Thepen T, Bruijnzeel-Koomen CA, van Reijsen FC: Clinical and immunologic variables in skin of patients with atopic eczema and either positive or negative atopy patch test reactions. J Allergy Clin Immunol 2000;105: 1008-1016. 